\title{
Cardiovascular imaging in patients with suspected arrhythmogenic right ventricular cardiomyopathy
}

\section{DIgor Klarić*, DDamir Raljević, (D) Vesna Pehar Pejčinović, \\ DViktor Peršić, \\ (D) Karlo Stanić, (DIvo Kalčić}

Thalassotherapia Opatija, Clinic for rehabilitation, treatment and prevention of diseases of the heart and blood vessels, Opatija, Croatia
KEYWORDS: arrhythmogenic right ventricular cardiomyopathy, cardiovascular imaging, 2D echocardiography, 3D echocardiography, cardiac magnetic resonance. CITATION: Cardiol Croat. 2019;14(3-4):63. | https://doi.org/10.15836/ccar2019.63

*ADDRESS FOR CORRESPONDENCE: Igor Klarić, Thalassotherapia Opatija, Ul. Maršala Tita 188, HR-51410 Opatija, Croatia. / Phone: +385-51-202-664 / E-mail: iklaric78@gmail.com

ORCID: Igor Klarić, https://orcid.org/0000-0003-1894-1477 • Damir Raljević, https://orcid.org/0000-0001-9743-9201 Vesna Pehar Pejčinović, https://orcid.org/0000-0002-8921-7999 • Viktor Peršić, https://orcid.org/0000-0003-4473-5431 Karlo Stanić, https://orcid.org/0000-0003-2056-8958 • Ivo Kalčić, https://orcid.org/0000-0001-7724-7296

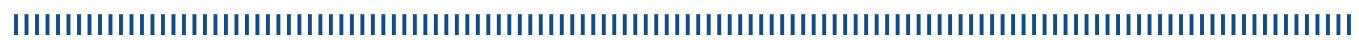

Arrhythmogenic Right Ventricular Cardiomyopathy (ARVC) is a hereditary cardiomyopathy that is histologically characterized by progressive replacement of the right ventricular myocardial tissue by fibrofatty tissue and usually manifests from the second to fourth decade of life with ventricular arrhythmias origin from the right ventricle, sudden cardiac death and / or abnormal contractility of the right ventricle. Today, it is known that this replacement of normal myocardial of RV with fibrofatty tissues the result of the mutation of five genes encoding heart desmosome proteins responsible for connecting cardiomyocytes. ${ }^{1-4}$ Typical morphological features of ARVC are regional contractility disorders, aneurysm, or dyssynchrony of the right ventricle contractions. These abnormalities are typically observed in predilection areas involving the subtricuspidal area, the free wall of basal segment RV and the posterolateral wall of LV. The 2010 Revised Task Force criteria for ARVD clearly highlighted the importance of cardiovascular imaging in diagnosing this clinical entity, primarily keeping in mind 2D echocardiography and cardiac magnetic resonance. They have become widely available, especially 2D echocardiography, are non-invasive and do not expose patients to ionizing radiation. Although not included in the diagnostic criteria, studies confirm that echocardiographic imaging methods using a TDI or speckle tracking are tool which allow us to notice early changes in RV function. Cardiac magnetic resonance has the ability of 3D visualization and high spatial resolution, and also provides both morphological and functional characterization as well as estimation of fibrofatty replacement, and is the gold standard for final diagnosis, while 2D echocardiography serves in clinical follow-up and has shown significant variability in the rate of progression disease.
RECEIVED:

February 28, 2019

ACCEPTED:

March 24, 2019

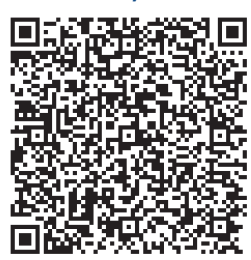

LITERATURE IIIIIIIIIIIIIIIIIIIIIIIIIIIIIIIIIIIIIIIIIIIIIIIIIIIIIIIIIIIIIIIIIIIIIIIIIIIIIIIIIIIIIIIIIIIIIIIIIIIIIII

1. Cho Y. Arrhythmogenic right ventricular cardiomyopathy. J Arrhythm. 2018 Mar 11;34(4):356-368. https://doi.org/10.1002/joa3.12012

2. Te Riele ASJM, Tandri H, Sanborn DM, Bluemke DA.Noninvasive multimodality imaging in ARVD/C. JACC Cardiovasc Imaging. 2015 May;8(5):597611. https://doi.org/10.1016/j.jcmg.2015.02.007

3. Kayser HW, van der Wall EE, Sivananthan MU, Plein S, Bloomer TN, de Roos A. Diagnosis of arrhythmogenic right ventricular dysplasia: a review. Radiographics. 2002 May-Jun;22(3):639-48; discussion 649-50. https://doi.org/10.1148/radiographics.22.3.g02ma07639

4. Wang W, James CA, Calkins H. Diagnostic and therapeutic strategies for arrhythmogenic right ventricular dysplasia/cardiomyopathy patient. Europace. 2019 Jan 1;21(1):9-21. https://doi.org/10.1093/europace/euy063 